DR PHILIP CASS is postgraduate programme leader in the Department of Communication Studies at Unitec in Auckland.

\section{Some bright spots in the gloom}

Australian Journalism Today, edited by Matthew Ricketson. Melbourne: Palgrave Macmillan, 2012. 258pp. ISBN 9781420256727.

A cof essays, Australian journalism is in a parlous state, beset by public mistrust, new demands of technology, the insidious influence of public relations and the greed and short-sightedness of newspaper proprietors.

We have been here before, of course, and journalists and good reporting have managed to survive, but the challenges are bigger than they have been in the past. Neither have journalists had to contend with quite such a lack of acknowledgement of their professional status.

The distinctive professional status of journalism has been eroded by the widespread belief that anybody with a mobile phone camera is a reliable source and the marginalisation or

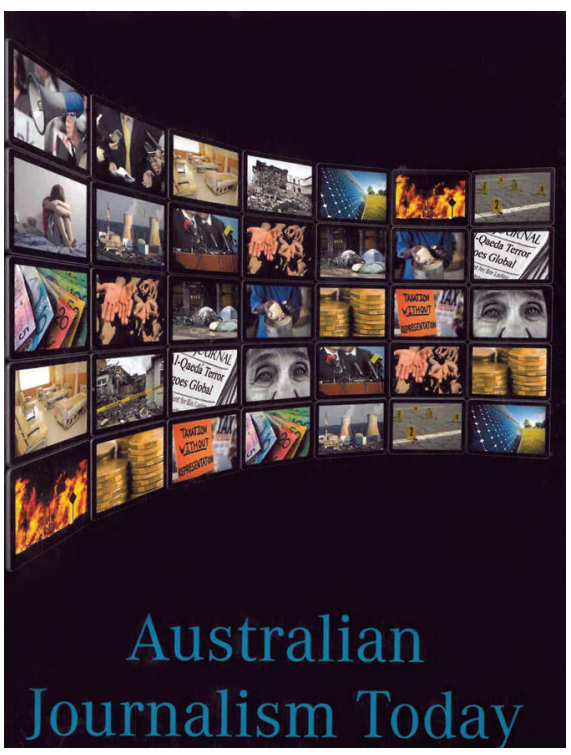

destruction of journalism courses in too many tertiary institutions.

Journalists have also risked being 'de-skilled' by proprietors who decided that every journalist should now take their own photographs, video footage and write stories for several different media, thus allowing them to sack lots of specialised staff. At the same time as they were saving money by sacking staff, they failed utterly to develop an economic model that would allow them to distribute material on the net sensibly and profitably.

The result has been swingeing job losses, amalgamations of subbing operations, the cloning of content from one title and platform to another and the reduction of state dailies like The Courier Mail to tabloid junk.

246 PACIFIC JOURNALISM REVIEW 19 (2) 2013 
These effects can be seen to even more dramatic effect in New Zealand where the news is all too often reduced to stories about the Black Balls beating Wallis and Futuna in petanque, cats being rescued from trees and brave dads sacrificing their lives to save their drowning children (or bursting into tears because they have accidentally run over them).

So, is there any hope for the profession and the audience which relies on it for accurate, balanced, timely news reporting and calm, informed analysis?

While Ricketson's collection presents a gloomy picture of journalism beset by idiocy and technology, his authors do offer some solutions, or at least some signs that something good can come from all of this.

Aileen Berry makes the sensible point that the media industry is a business. One only has to remember the fate of any number of other good newspapers and magazines to acknowledge that no amount of good journalism will balance an absence of advertising. Alas, there is good business and bad business. Good business practices give us the kind of journalism that keeps governments in line. Bad business practices hope we'll prefer the Kardashians (or the Ridges, if you live in New Zealand).

Berry's chapter gives us a better perspective on some of the other chapters, such as Nick Richardson's take on the survival and continued popularity of such phenomena as purely local news sources and microbroadcasters.

There are some useful chapters on how good journalism can survive and possibly thrive. Not all of the ideas are particularly new. Foundations and non-profit trusts have existed for years, but have existed primarily in countries where the rich have a tradition of philanthropy and public service not often seen in the Antipodes. There have been exceptions to this in Australia where joint projects have led to in-depth, quality reporting of major subjects from which too many media organisations now shy away. On this side of the Ditch, a recent example has been the announcement of the Scoop Foundation Project.

As Peter Browne points out in his chapter on funding newsrooms, some organisations have taken advantage of the very technology which has threatened so many other newspapers. By using its reputation for quality journalism, the UK Guardian has made itself the second best-read English newspaper in the world. Elsewhere, the New York Times has taken the risk of installing a pay wall and offering subscriber-only material.

The other method of ensuring continued financial support for the 
press is the model found in some European countries where the government provides subsidies to ensure there is diversity in the market and the survival of papers serving niche communities.

Sometimes knowing about the dangers facing them enables journalists to prepare their defences. Good journalists have always regarded public relations as the work of Satan, but as Andrew Dood points out in a chapter entitled 'The hidden underbelly of the journalism-public relations nexus', the practitioners of this dark art have established a firm foothold in the boardrooms of countries like Australia where they train corporate mouthpieces to sound sincere and truthful and to control the news to their own advantage.

The extent of their influence is frightening. As Nick Davies pointed out in Flat Earth News, the media all too often fall prey to what he calls churnalism, the endless recycling of press releases, puff pieces and nonstories by cash-strapped (or simply lazy) news services.

Sometimes the book makes you wonder how on earth some of these problems arose. The acquisition of a 24-hour news service seems to have become a matter of prestige rather than common sense, like drinking Perrier instead of tap water. The
$\mathrm{ABC}$ now has a 24-hour news service, albeit at the expense of funding for flagship programmes like Four Corners. Since every 24-hour news service is recycling the same bits of news footage from Reuters (or the same magazine stories from Journeyman Pictures) it hardly seems logical for the $\mathrm{ABC}$ to have gone down this path. It could just as easily have rebroadcast BBC World or France 24 and dropped in a half hour bulletin of its own at breakfast time.

As Ricketson points out in his own chapter, 'The Appreciation of Long Form Journalism,' the introduction of 24-hour news cycles has led to a situation where journalists no longer explain or seek the truth, but loudly state something to be so. However, there are signs that not all is lost. While Newsweek has ceased publishing in hard copy and The Bulletin disappeared from Australian newsagents' shelves long ago, sales of publications like The Economist and The Atlantic, which carry longer, in-depth stories, have risen. Ricketson links this to the tradition of non-fiction reporting that began for modern journalists with Truman Capote's book In Cold Blood and progressed through several drug-hazed volumes by Hunter S.Thompson and Tom Wolfe. This would indicate that there is an audience out there 
which wants nuanced and informed reporting and is prepared to put in the time to read it. Having the time and the financial support to write a bookand knowing there was an intelligent, receptive audience out there - would be an incentive for any journalist.

Some of the ideas in Ricketson's book are a little curious. To a journalist raised on the notion that news and commentary must be kept firmly separated, Stephen Harrington's suggestion that journalists could learn anything from satirists and pranksters like the Chasers seems bizarre, at best. They might be entertaining, but they are not news. They may produce comment, but that is a function that should be kept firmly firewalled from the news. Audiences must know that what they are seeing is honest, balanced, reporting; otherwise it is just entertainment.

I'm not sure all of the chapters should have been here. Peter Clarke's chapter on interviewing would sit better in a training manual. Kimina Lyall's chapter on trauma is interesting, but while I sympathise with the distress she experience while covering the Port Arthur shooting, I'm afraid that I would have to agree with her chief of staff who told her: 'If you want to be a journalist you have to learn to cope with this stuff.'

In a way this book is all about learning to cope with this stuff. Australian Journalism Today is, in the main, a worthwhile survey of some of the problems facing Australian journalists. It doesn't offer all the solutions, but it is a good place to start.

S

